\title{
Motivação de crianças para aprendizagem do violão no contexto do ensino coletivo
}

\section{Children's motivation for learning guitar in collective classes}

\footnotetext{
* Doutoranda no Programa de Pós-Graduação em Música da Universidade Federal do Paraná (UFPR), na linha de pesquisa Educação Musical e Cognição. Mestra em Música pela UFPR.

** Professora Associada da Universidade Federal do Paraná (UFPR). Docente nos cursos de graduação e pós-graduação em música. Bolsista de produtividade do CNPq e coordenadora do Programa de Pós-Graduação em Música da UFPR. Doutora em Música pela UFRGS. Realizou pós-doutorado na Universidade de Bolonha.
} 


\section{Resumo}

O estudo das "Crenças de Autoeficácia" é uma das possibilidades para orientar investigações sobre a motivação, uma vez que a confiança nas próprias habilidades está relacionada a aspectos intrínsecos e extrínsecos do processo motivacional. Assim, o escopo para este estudo foi investigar a motivação de crianças para aprender violão sob a ótica das crenças de autoeficácia, num contexto de ensino coletivo. A metodologia foi um Estudo de Levantamento de pequeno porte, realizado com sete crianças entre 9 e 11 anos de idade, e a coleta de dados foi feita por meio de questionário com perguntas abertas e questões com resposta no formato de escala Likert. Os resultados indicaram aspectos da motivação geral das crianças sobre a aprendizagem em grupo, repertório e performance pública, na relação com suas crenças de autoeficácia. Neste sentido, foi observado que as experiências vicárias estavam presentes nas aulas e que os estudantes valorizavam a possibilidade de aprender com os outros; que as experiências de êxito eram pouco percebidas pelas crianças; que os estados fisiológicos eram mais controlados no contexto da performance em conjunto; e que a persuasão verbal vinda do professor possuía efeito positivo maior para o aumento das crenças de autoeficácia nos estudantes em detrimento da persuasão dos colegas. Concluiu-se que os resultados da pesquisa corroboraram com estudos anteriores sobre a aprendizagem em contexto coletivo, demonstrando o potencial que tal contexto traz para motivação do aluno, além de permitir vislumbrar sugestões para que o professor possa contribuir na manutenção da motivação dos estudantes e, consequentemente, para o aumento das suas crenças de autoeficácia.

Palavras-chave: Motivação; Crenças de Autoeficácia; Ensino Coletivo; Crianças; Violão.

\section{Abstract}

Self-Efficacy Beliefs Theory is one of the possibilities for guiding research about motivation, since trust in one's own abilities reinforces intrinsic and extrinsic aspects of the motivational process. Thus, the scope of our study was to investigate the motivation of children learning to play guitar from the perspective of self-efficacy beliefs in a context of collective teaching. The methodology was a small survey, carried out with seven children 9 - 11 years old, and the data collection was done through a questionnaire with open questions, and questions with response in the likert scale format. Results showed aspects of children's general motivation regarding group learning, repertoire and public performance, in relation to their self-efficacy beliefs. We observed the presence of vicarious experiences during the classes, and that students valued the possibility of learning from others; successful experiences were poorly perceived by the children; the emotional and physiological state of the children was more controlled in the context of collective performance; verbal persuasion from the teacher had a stronger positive effect on increasing students' self-efficacy beliefs when compared to the persuasion of their peers. Results of this research corroborated with previous studies about learning in a collective context, demonstrating the potential that such a context adds to students' motivation. In addition, suggestions were offered to the teacher to help maintain the motivation of the students and, consequently, to increase their self-efficacy beliefs.

Keywords: Motivation; Self-efficacy Beliefs; Collective Teaching; Children; Guitar. 


\section{Introdução}

A relação entre a motivação e a aprendizagem tem sido estudada por diferentes óticas, tanto sob o ponto de vista dos alunos quanto sob o ponto de vista dos professores (GALAND; BOURGEOIS, 2011). Ao focarmos o ponto de vista do aluno, é possível enfatizarmos elementos sociais e cognitivos que incluem tanto fatores internos quanto fatores externos à aprendizagem (Idem). Dentre as atuais teorias da motivação que tratam sobre elementos sociais/cognitivos da aprendizagem, podemos citar o estudo das crenças de autoeficácia como uma das possibilidades para orientar investigações sobre a relação dos estudantes com a motivação. As crenças de autoeficácia, principal constructo da Teoria Social Cognitiva de Albert Bandura, estão relacionadas a quanto um indivíduo se julga capaz de realizar determinada tarefa. Pajares e Olaz (2008, p. 101) afirmam que as crenças de autoeficácia "[...] são percepções que os indivíduos têm sobre suas próprias capacidades". Não é questão de conseguir ou não realizar a tarefa, mas sim de quanto a pessoa acredita ser capaz de realizá-la. De acordo com Pajares (apud McPHERSON; O'NEILL, 2002, p. 34),

\footnotetext{
Crenças de autoeficácia atuam como determinantes do comportamento, influenciando as escolhas que os indivíduos fazem, o esforço que eles despendem, a perseverança que eles conservam diante de dificuldades, e os padrões de pensamento e reações emocionais que experimentam. (McPHERSON; O'NEILL, 2002, p. 34, tradução nossa).
}

Neste artigo apresentamos dados de uma pesquisa de natureza qualiquantitativa, cujo principal objetivo foi investigar a motivação para aprender violão em grupo (aulas coletivas) a partir das fontes de influência das crenças de autoeficácia (experiências diretas, experiências vicárias, persuasão verbal - do professor/dos colegas - e indicadores fisiológicos - rubor facial, suor, batimento cardíaco acelerado etc.). Foram analisados e discutidos os dados coletados por meio de um estudo de levantamento de pequeno porte, com aplicação de questionários com questões abertas, fechadas e com escala Likert, respondidos por alunos que aprendiam violão em grupo, em uma instituição de ensino da cidade Curitiba (PR). Os respondentes tinham entre 9 e 42 anos de idade e, para este artigo, selecionamos especialmente os dados de sete alunos com idade inferior a 12 anos, que são considerados crianças de acordo com o Estatuto da Criança e do Adolescente. $^{2} \mathrm{O}$ motivo para destacar a contribuição das crianças nesta pesquisa foi o nosso interesse em observar aspectos sobre a motivação específica delas, no contexto da aprendizagem coletiva. Vários são os estudos sobre aprendizagem musical em ambiente coletivo no Brasil (TOURINHO, 1995, 2002; STENCEL; SOARES e MORAES, 2012; CRUVINEL, 2003; VIEIRA e RAY, 2007; TEIXEIRA, 2008; BRAGA, 2009; RIBEIRO, 2013; BRAZIL, 2013a, 2013b), no entanto, estudos que deem voz às crianças ainda precisam ser mais explorados. Pretendemos, com o enfoque desta investigação, contribuir com pesquisas que relacionam a aprendizagem musical de crianças em ambiente coletivo e motivação, especialmente sob a ótica das crenças de autoeficácia. 


\section{Crenças de autoeficácia}

Depois de diversas alterações, em 1997 Bandura chegou à seguinte definição para o constructo da autoeficácia: "Auto-eficácia percebida refere-se às crenças de alguém em sua capacidade em organizar e executar cursos de ação requeridos para produzir certas realizações"1 (BANDURA apud AZZI e POLYDORO, 2006, p. 12).

Esta é a definição adotada neste trabalho, na qual a percepção da autoeficácia do indivíduo está relacionada com as suas "[...] possibilidades pessoais (crenças de capacidade) de ser agente na produção da própria trajetória (organizar e executar) destacando que a concepção de auto-eficácia está relacionada a metas e objetivos" (AZZI e POLYDORO, 2006, p. 14).

Grande parte da motivação humana é gerada cognitivamente, pelo exercício da antecipação. As pessoas formam crenças a respeito do que são capazes de fazer, antecipam resultados prováveis de ações futuras e definem metas para si mesmas, planejando as ações necessárias para realizar o futuro da forma que visualizaram (BANDURA, 1994).

Não há dúvidas de que as crenças de auto-eficácia contribuem para a motivação de várias maneiras. Determinam as metas que as pessoas estabelecem para si próprias, quanto esforço elas investem, por quanto tempo persistem diante de dificuldades e quão resilientes são em relação aos próprios fracassos. Aqueles que acreditam mais em si e em suas capacidades exercem mais esforço diante de dificuldades e esse exercício de esforço, por sua vez, reverte-se em melhores realizações. (COSTA; BORUCHOVITCH, 2006, p. 94).

Pessoas com crenças de eficácia fortalecidas enxergam as dificuldades como desafios a serem superados e atribuem eventuais fracassos ao esforço insuficiente ou à falta de conhecimentos/habilidades que podem ser adquiridas. Por outro lado, pessoas que não acreditam em suas capacidades veem tarefas difíceis como ameaças pessoais e se intimidam diante delas. Tendem a ter baixas aspirações e não persistir em seus objetivos (BANDURA, 1994).

Cereser (2011) esclarece que, diferentemente da autoestima e do autoconceito, isto é, um julgamento sobre si ou seus sentimentos, as crenças de autoeficácia se referem ao julgamento da pessoa acerca de sua capacidade de realizar uma determinada tarefa, sendo que esse julgamento pode ser modificado com o tempo.

Quatro principais fontes de influência são responsáveis por desenvolver as crenças das pessoas sobre sua eficácia: (1) experiências diretas, quando o indivíduo obtém sucesso na realização de algo; (2) experiências vicárias, que estão ligadas à capacidade do ser humano de aprender observando modelos sociais; (3) persuasão verbal ${ }^{2}$, quando outras pessoas a convencem sobre sua capacidade; (4) indicadores fisiológicos, que se referem à forma como o indivíduo percebe e interpreta suas reações emocionais e físicas (rubor facial, sudorese nas mãos, respiração e batimentos cardíacos acelerados) (BANDURA, 1994).

\footnotetext{
1 As citações diretas foram fielmente transcritas, inclusive palavras grafadas fora do Novo Acordo.

2 Alguns trabalhos traduzem esta fonte de autoeficácia como persuasão social.
} 
A experiência direta de êxito, além de ser a primeira fonte citada, é a fonte mais efetiva e que produz maior influência no desenvolvimento de um senso de autoeficácia fortalecido, pois baseia-se nas experiências reais da pessoa. O senso de autoeficácia pessoal é fortalecido quando se obtém sucesso nas tarefas. Porém, quando um aluno obtém sucesso com muita facilidade, pode se desencorajar rapidamente diante dos fracassos, pois tende a esperar resultados a curto prazo (COSTA; BORUCHOVITCH, 2006). De acordo com Azzi e outros (2014, p. 25), "um dos aspectos importantes desse tipo de fonte, e que vai além dos resultados obtidos na realização da tarefa, é o fornecimento de informação acerca da capacidade e não apenas o desempenho obtido".

Resultados interpretados como bem-sucedidos aumentam a auto-eficácia, ao passo que os que são interpretados como fracassos a reduzem. Claro que pessoas com um sentido baixo de auto-eficácia muitas vezes fazem pouco caso de seus sucessos, em vez de mudarem a crença. Mesmo depois de alcançar um objetivo por meio de seus esforços persistentes, alguns indivíduos continuam a duvidar de sua eficácia para fazer um esforço semelhante. Consequentemente, as experiências de domínio são apenas dados brutos, e muitos fatores influenciam a maneira como tais informações são processadas cognitivamente e afetam a auto-avaliação do indivíduo. (PAJARES; OLAZ, 2008, p. 104).

Uma vez estabelecido, o senso de autoeficácia fortalecido em um domínio específico tende a ser generalizado para outras situações em que o desempenho foi debilitado pela preocupação com insuficiências pessoais (BANDURA, 1977, p. 195, tradução nossa3).Além das experiências diretas, as crenças de autoeficácia das pessoas são formadas por meio das experiências vicárias, que consistem na observação de modelos sociais. Ao observar os pares com capacidades análogas executando tarefas com sucesso, o aluno fortalece a crença de que possui condições para aprender e executar as mesmas tarefas com sucesso (COSTA; BORUCHOVITCH, 2006).

Pela mesma razão, ao observar o outro fracassar, mesmo se esforçando muito, o julgamento na sua própria eficácia diminui e seus esforços são prejudicados (BANDURA, 1994). Costa e Boruchovitch (2006, p. 98) reforçam que "o modelo social deve ser visto pelo aluno como possuindo características cognitivas similares às dele, bem como possuir competências que ele almeje alcançar". Ainda sobre a semelhança entre o modelo e o observador, Bandura esclarece:

Quanto maior a semelhança com o modelo, mais persuasivos serão os sucessos e falhas do modelo. Se as pessoas vêem os modelos como muito diferentes de si, sua autoeficácia não é tão influenciada pelo comportamento dos modelos e os resultados que produzem (BANDURA, 1994, p. 72, tradução nossa4).

\footnotetext{
3 "Once established, enhanced self-efficacy tends to generalize to other situations in which performance was self-debilitated by preoccupation with personal inadequacies" (BANDURA, 1977, p. 195).

$4 \quad$ "The greater the assumed similarity the more persuasive are the models' successes and failures. If people see the models as very different from themselves their perceived self-efficacy is not much influenced by the models' behavior and the results its produces" (BANDURA, 1994, p. 72).
} 
Contudo, as influências de modelos fazem mais do que fornecer um parâmetro social de comparação das próprias capacidades. As pessoas buscam modelos com as competências que elas desejam ter (BANDURA, 1994). Segundo Pajares e Olaz (2008), ter um modelo relevante na vida do sujeito pode suscitar crenças pessoais que servirão de influência para o indivíduo, sobre o rumo e o sentido de sua vida

De acordo com Pajares e Olaz (2008, p. 100), "as pessoas não aprendem apenas com suas experiências, mas também observando os comportamentos de outras pessoas". Dessa forma, é possível aprender sem passar pelo processo de tentativa e erro, e essa aprendizagem por meio da experiência vicária pode, muitas vezes, evitar que as pessoas cometam os mesmos erros observados. Dando continuidade à essa ideia, os autores explicam que

A aprendizagem observacional é governada pelos processos de atenção, retenção e motivação. A atenção refere-se à capacidade do indivíduo de observar as ações de um modelo seletivamente. De sua parte, os comportamentos observados somente podem ser reproduzidos se forem retidos na memória, um processo possibilitado pela capacidade humana de simbolizar. A produção refere-se ao processo de realizar o comportamento observado. Finalmente, se a realização do comportamento observado produzir os resultados desejados, o indivíduo se sente motivado para adotar o comportamento e repeti-lo no futuro. (PAJARES; OLAZ, 2008, p. 101).

A persuasão verbal é a terceira forma de fortalecer a crença do indivíduo de que ele já possui o que é preciso para obter sucesso (BANDURA, 1994). Ela é amplamente utilizada na tentativa de influenciar o comportamento humano, principalmente pela sua fácil e pronta disponibilidade. As pessoas são conduzidas, por meio de sugestões, a acreditar que podem enfrentar com sucesso aquilo que as oprimiu no passado (BANDURA, 1977). Porém, “[...] tal julgamento possui um efeito limitado sobre as crenças de eficácia, principalmente se a persuasão for acompanhada por um fracasso" (COSTA e BORUCHOVITCH, 2006).

Em outras palavras, as crenças de eficácia pessoal induzidas pela persuasão verbal tendem a ser mais frágeis do que as crenças decorrentes das realizações próprias do indivíduo, pois elas não são formadas a partir de experiências reais do sujeito. Além disso, é muito mais fácil enfraquecer as crenças de autoeficácia do indivíduo através da persuasão verbal do que fortalecê-las. Dessa forma, o indivíduo que foi convencido de que não possui capacidades tende a evitar atividades desafiadoras e a desistir frente às primeiras dificuldades (BANDURA, 1994).

Os construtores de eficácia bem-sucedidos fazem mais do que manifestar avaliações positivas. Além de aumentar a crença das pessoas em suas próprias capacidades, eles estruturam situações de forma que elas obtenham sucesso e evitam colocá-las prematuramente em situações onde tendem a falhar com frequência. Eles medem o sucesso em termos de autodesenvolvimento ao invés de medi-lo em termos de triunfos sobre os outros. (BANDURA, 1995, p. 4, tradução nossa ${ }^{5}$ ).

$5 \quad$ "Successful efficacy builders do more than convey positive appraisals. In addition to raising people's beliefs in their capabilities, they structure situations for them in ways that bring success and avoid placing people in situations prematurely where they are likely to fail often. They measure success in terms of self-improvement rather than by triumphs over others" (BANDURA, 1995, p. 4). 
Os construtores de eficácia bem-sucedidos, também chamados de persuasores efetivos, desempenham um importante papel no desenvolvimento das crenças de um indivíduo. "Porém, as persuasões sociais não devem ser confundidas com elogios ou louvores vazios. Os persuasores efetivos devem cultivar as crenças das pessoas em suas capacidades, enquanto garantem que o sucesso imaginado é alcançável" (PAJARES e OLAZ, 2008, p. 105).

Os indicadores fisiológicos, também conhecidos como estados somáticos e emocionais, influenciam o julgamento das pessoas sobre suas capacidades. "A redução do estresse e a alteração de estados emocionais negativos auxiliam o controle do raciocínio, melhorando a crença de auto-eficácia" (COSTA E BORUCHOVITCH, 2006, p. 99).

Bandura (1994) esclarece que não é a pura intensidade das reações emocionais e físicas que importam, mas, sim, como essas reações são percebidas e interpretadas pelo sujeito. Aqueles que possuem um senso de autoeficácia fortalecido tendem a interpretar as alterações em seus indicadores fisiológicos como um facilitador energizante da performance, enquanto os indivíduos que não acreditam na própria capacidade interpretam as mesmas alterações como algo que irá prejudicar a performance.

As pessoas podem avaliar o seu grau de confiança por seu estado fisiológico enquanto pensam em uma determinada ação. Reações emocionais fortes a uma tarefa fornecem pistas sobre a previsão de sucesso ou fracasso. Quando as pessoas têm pensamentos negativos e temores sobre suas capacidades, as reações afetivas podem reduzir as percepções de auto-eficácia e desencadear mais estresse e agitação, que ajudam a causar o desempenho inadequado e temido. Uma maneira de aumentar as crenças de auto-eficácia é promover o bem-estar emocional e reduzir estados emocionais negativos. (PAJARES e OLAZ, 2008, p. 105).

\section{O ensino coletivo de instrumentos musicais}

O ensino coletivo de instrumentos musicais tem despertado grande interesse dos pesquisadores e educadores musicais nos últimos anos, reforçando a ideia de tornar o ensino musical acessível a mais pessoas. Cruvinel (2003) destaca a importância desta ferramenta quanto ao seu aspecto democrático para o ensino:

O Ensino Coletivo é uma importante ferramenta para o processo de democratização do ensino musical, contribuindo de forma bastante significativa neste processo. A musicalização através do ensino coletivo pode dar acesso a um maior número de pessoas à Educação Musical, aumentando a razão professor/ aluno por esforço hora/aula ministrada. (CRUVINEL, 2003, p. 2).

Entre as vantagens do ensino coletivo de instrumentos musicais, Cruvinel (2003) indica: a interação entre os alunos; o ambiente lúdico; o desenvolvimento do repertório; a afinação do grupo; o desenvolvimento do ouvido harmônico; a economia de tempo; a baixa desistência de alunos; a melhora da autoestima dos alunos; maior rendimento, estímulo, disciplina; cooperação; e desinibição. Dentre as desvantagens, a autora inclui, 
por exemplo, a dificuldade de lidar com turmas heterogêneas. Tourinho (2010) também destaca vantagens e desvantagens do ensino coletivo:

Algumas vantagens pedagógicas são óbvias, como a) o atendimento ao maior número de pessoas em menos tempo de trabalho; b) menor desgaste para o professor com as aulas iniciais, onde se repete menos as informações básicas; c) os estudantes aprendem uns com os outros, por observação mútua e auto avaliação intuitiva; d) os parâmetros musicais são adquiridos mais rapidamente. [...] As desvantagens que aponto se referem à dificuldade de administrar diferenças individuais de aprendizagem, inclusive de temperamento e gosto musical, disciplina, assiduidade, pontualidade e estudo em casa. (TOURINHO, 2010, p. 86-87).

Além dos aspectos citados por Tourinho e Cruvinel - nos quais se observa elementos comuns citados pelas autoras, como a aprendizagem por meio da interação e do estímulo proveniente do contexto, a cooperação e a economia de tempo com atendimento a grande número de pessoas, inclusive a desvantagem da dificuldade de lidar com diferenças individuais -, Caetano (2012) sintetiza mais alguns dados sobre a prática musical em grupo:

Observa-se que, na prática em grupo, o aluno necessita ouvir atentamente os colegas, possibilitando assim o maior desenvolvimento da percepção musical. Os alunos têm mais elementos para avaliar o seu desempenho, pois eles são acostumados a tocar em conjunto e a ouvir uns aos outros desde o início, desenvolvendo, dessa forma, o juízo crítico e estético. (CAETANO, 2012, p. 41).

Neste sentido, Caetano também corrobora com o pensamento de Cruvinel e Tourinho ao indicar que o ambiente coletivo possibilita o desenvolvimento da percepção (citado por Cruvinel com a melhora da afinação e do desenvolvimento do ouvido harmônico) e facilita a avaliação do próprio desempenho (por meio de observação e autoavaliação, citadas por Tourinho). No ambiente propiciado pelo ensino coletivo de instrumentos musicais, diversos são os fatores que podem influenciar a motivação dos alunos. Por exemplo, para Cruvinel (2003 p. 190), "o resultado musical acontece de maneira rápida, motivando os alunos a darem continuidade ao estudo do instrumento". Caetano (2012) também comenta sobre a velocidade do desenvolvimento musical e a competição saudável que surge no grupo:

É apontado que o desenvolvimento, no coletivo, se dá de forma mais acelerada, perceptível e a sonoridade obtida no grupo é melhor. O desenvolvimento musical relativamente rápido motiva os alunos a continuarem os estudos. A competição saudável que surge no grupo também estimula o aprendizado de forma positiva. $O$ aluno passa a se desenvolver individual e coletivamente, apresenta maior comprometimento nesses dois campos, ampliando a socialização e fomentando uma postura mais ativa. (CAETANO, 2012, p. 38).

Dentre os diversos fatores que contribuem para a motivação do aluno, Dantas (2010, p. 411) destaca "[...] a oportunidade de aprender em conjunto, o fato de sentir-se parte de um grupo musical, a atuação e o estímulo do professor, e a sonoridade do gru- 
po". Isto é, o sentimento de pertencimento, a relevância dada ao produto sonoro, bem como a atuação do professor no contexto do grupo, são elementos que promovem a motivação e engajamento do estudante. Neste contexto, portanto, "[...] o aluno é motivado a aprender, tendo o professor como facilitador e os colegas como espelho e, assim, passa a compreender que cada um constrói seu próprio conhecimento" (ORTINS; CRUVINEL; LEÃO, 2004, p. 62). Além disso, segundo Braga (2009, p. 135), "[...] quando os alunos são colocados como modelos, sujeitos capazes de auxiliar os colegas, e de compartilharem a responsabilidade pela aprendizagem do grupo com o professor, a tendência é que estes se sintam mais motivados e incorporem o espírito de equipe".

Condessa (2011) investigou os fatores individuais e ambientais que motivam os alunos a continuarem seus estudos em música. A autora destaca que "a opinião dos colegas, o sentimento de pertencer a um grupo, a formação da identidade entre os amigos, a escolha de valores e os tipos de comportamentos influenciam diretamente a motivação para aprender em diferentes contextos de aprendizagem" (CONDESSA, 2011 p. 29). Dentre os fatores individuais, destaca-se a percepção da própria evolução no aprendizado do instrumento, conforme detalham os autores:

\begin{abstract}
Verifica-se que o fator que mais os motivam a permanecer no grupo é a aprendizagem instrumental, o que põe em evidência que mesmo sendo ensino coletivo, os alunos estão aprendendo seja com a facilitadora do processo ou com os colegas como espelho, ou ainda pelo papel do professor de facilitador do processo ensino/aprendizagem e das relações interpessoais. (ORTINS; CRUVINEL; LEÃO, 2004, p. 66).
\end{abstract}

Revisando a literatura sobre o ensino coletivo de instrumentos musicais, tendo o violão como principal instrumento utilizado, foram encontrados alguns trabalhos no contexto brasileiro. Um dos primeiros e mais representativos trabalhos é a dissertação de Tourinho (1995), cujo objetivo foi "observar o desempenho musical na aula de violão em grupo através do repertório de interesse desses alunos" (TOURINHO, 2002, p. 1). Tourinho $(2006$, p. 1) observa que "[...] ensinar violão (ou outros instrumentos) de forma coletiva é atualmente uma realidade para muitos professores que trabalham com estudantes iniciantes, que vão ter o primeiro contato com o instrumento escolhido". Outros artigos da autora tiveram como objetivo abordar os aspectos educacionais, princípios de organização e dinâmica das aulas coletivas de violão para a comunidade de Salvador, oferecidas pela Universidade Federal da Bahia (TOURINHO, 2010; TOURINHO; AZZI, 2014).

Ribeiro (2013), em sua tese, tratou sobre concepções do ensino coletivo de instrumentos musicais na modalidade a distância, sob o viés da autodeterminação, verificando a motivação para aprender nas aulas de violão à distância (on-line). Seu tema se aproximou ao tema da presente pesquisa ao relacionar o estudo do ensino coletivo de instrumento ao estudo da motivação para aprendizagem, porém, neste caso, sob o viés de outra teoria motivacional, a teoria da autodeterminação, que tem como foco principal as relações entre as motivações intrínseca e extrínseca, na ação do indivíduo.

Professores de violão e seus modos de ser e agir na profissão foram o tema da dissertação de Vieira (2009) e, dentre as metodologias de trabalho relatadas pelos pro- 
fessores entrevistados, estavam as aulas de violão em grupo. De acordo com o autor, "[...] essa modalidade de aula parece compor um importante sistema de organização, bastante próprio da cultura profissional desses professores" (VIEIRA, 2009, p. 113).

Cruvinel (2003), por sua vez, investigou os efeitos do ensino coletivo na iniciação instrumental de cordas, citando o ensino coletivo de violão em diversos momentos. $\mathrm{E}$, finalmente, os artigos de Brazil (2013a, 2013b) e de Brazil e Tourinho (2013) trataram das crenças de autoeficácia no ensino coletivo de violão, apresentando alternativas como composição coletiva, criação de arranjos e material didático, além de refletir sobre o uso das tonalidades no ensino de violão para iniciantes.

Outros trabalhos publicados sobre a temática do ensino coletivo do instrumento, mas que não trazem uma relação direta com o foco do presente artigo, são os estudos de Vieira e Ray (2007) e Braga (2009). Vieira e Ray (2007) apresentaram em seu artigo técnicas de arranjo de fácil compreensão para auxiliar os educadores musicais a lidarem com a falta de repertório e materiais didáticos para as aulas coletivas de violão. Braga (2009), por sua vez, estudou o ensino a distância em sua tese e seu objetivo principal foi relacionar os padrões de interação no curso de violão ao formato de Oficina de Violão a Distância.

\section{Metodologia e resultados}

Este estudo foi caracterizado como um levantamento de pequeno porte que contou com 21 participantes (organizados em diferentes turmas que tinham entre três e cinco alunos), sendo que, para este artigo, destacamos especialmente os dados das sete $(\mathrm{N}=7)$ crianças que participavam das aulas coletivas de instrumento. Nesta pesquisa os dados foram coletados com alunos que estudavam violão em aulas coletivas, a partir de um questionário previamente elaborado. As questões incluíam perguntas relativas aos dados de caracterização dos participantes, questões específicas sobre a motivação geral para a aprendizagem no ensino coletivo e sobre as fontes de eficácia. O questionário foi elaborado considerando que a população de alunos incluía estudantes acima de nove anos até a idade adulta. Neste sentido, não foram elaborados instrumentos diversos (específicos para crianças e adultos), por uma opção metodológica. Foi elaborado um questionário único, com questões fechadas, abertas e escala Likert (de cinco pontos), com uma apresentação objetiva e de fácil compreensão e aplicação, revisado e testado em estudo-piloto (publicado em BATTISTI e ARAÚJO, 2015). Todos os alunos responderam com facilidade ao instrumento.

Além da aplicação do questionário, foram realizadas quatro visitas ao campo empírico, para reconhecer o campo e compreender melhor o contexto da pesquisa (ver mais detalhes em BATTISTI, 2016). Sendo uma pesquisa de pequeno porte, entende-se que a validade do estudo é destacada na qualidade dos dados obtidos, que oferecem a compreensão dos elementos motivacionais dos sujeitos da pesquisa à luz do referencial teórico em questão, isto é, o estudo das crenças de autoeficácia na aprendizagem coletiva do violão. Tal estudo, por sua vez, traz implicações e referência para outros estudos semelhantes, aplicados em contextos diversos.

Das sete crianças que participavam da aula coletiva de violão, três eram do gênero 
feminino e quatro do gênero masculino; dois ( $N=2)$ possuíam nove anos de idade, três $(\mathrm{N}=3)$ possuíam dez anos e dois $(\mathrm{N}=2)$ possuíam onze anos. Todos eram iniciantes no estudo do violão, com aproximadamente um ano de estudo.

\section{Motivos para aprender violão}

As crianças foram questionadas sobre os motivos que as levaram a decidir aprender violão. A pergunta foi realizada numa questão em formato de múltipla escolha com uma série de alternativas contendo respostas ligadas à motivação intrínseca (MI) e extrínseca (ME) ou amotivação (AM). Eles podiam assinalar mais de uma alternativa. Os dois motivos mais recorrentes foram "Porque eu gosto do som do violão" e "Porque quero aprender novas habilidades", assinalados por quatro alunos; três crianças responderam "Porque eu gosto de música" e "Porque é importante para mim"; duas crianças assinalaram que decidiram aprender a tocar violão por ser divertido; e os motivos relacionados com o desejo de "tocar em uma banda", de "fazer novas amizades" e "outro motivo" foram assinalados cada um por um aluno. Os demais motivos (que incluíam questões sobre a influência dos pais e amigos e sobre amotivação) não foram assinalados pelos alunos nesta faixa etária. Os motivos assinalados estão detalhados em ordem decrescente no Quadro 1:

Quadro 1. Motivos para aprender violão

\begin{tabular}{lcc} 
& MI/ME & $\mathbf{N}$ \\
\hline Porque eu gosto do som do violão & MI & $\mathbf{4}$ \\
\hline Porque quero aprender novas habilidades & MI & $\mathbf{4}$ \\
\hline Porque é importante para mim & MI & $\mathbf{3}$ \\
\hline Porque eu gosto de música & MI & $\mathbf{3}$ \\
\hline Porque é divertido & MI & $\mathbf{2}$ \\
\hline Porque quero tocar em uma banda & ME & $\mathbf{1}$ \\
\hline Porque gostaria de fazer novas amizades & ME & $\mathbf{1}$ \\
\hline Outro motivo: & -- & $\mathbf{1}$ \\
\hline
\end{tabular}

Fonte: Dados da pesquisa

Os dois primeiros motivos para aprender violão, assinalados por quatro dos sete alunos, foram "Porque eu gosto do som do violão" e "Porque quero aprender novas habilidades". Esta motivação para aprender novas habilidades está relacionada com um aspecto teórico da motivação denominado necessidade por competência, formulado por Deci e Ryan (1985). De acordo com os autores: "[...] a cada nova aquisição de habilidade existe um espaço para se divertir exercitando essa nova habilidade, mas o tédio logo se instala quando o sujeito simplesmente exercita a mesma habilidade repetidas 
vezes" (DECl; RYAN, 1985, p. 27, tradução nossa6). Por este motivo, é importante haver um equilíbrio entre as habilidades que vão sendo adquiridas e os desafios propostos para adquirir novas habilidades. Dessa forma, o aluno vai se sentindo competente por meio das habilidades adquiridas e motivado pelo desafio de aprender outras novas.

Em segundo lugar vieram os motivos "Porque é importante para mim" e "Porque eu gosto de música". Esses resultados vão ao encontro dos resultados encontrados por Rosa (2015) em sua pesquisa sobre a motivação de adolescentes para o aprendizado de violão, sendo que $85 \%$ dos adolescentes indicaram "gostar de música" como o principal motivo para iniciar o aprendizado do violão. Araújo (2015, p. 53) constata que “[...] o envolvimento com a música e com as outras artes em geral é considerado, em senso comum, sempre prazeroso, agradável e de forte caráter intrínseco". Apesar desta ideia não ser sempre uma premissa (pois o aprendizado de um instrumento musical envolve empenho e motivação), ela pode ser relacionada com o motivo mais citado pelos alunos, que decidem aprender a fazer algo que gostam.

Em terceiro lugar, assinalado por dois alunos, foi o motivo "Porque é divertido" e, na sequência, "Porque quero tocar em uma banda" e "Porque gostaria de fazer novas amizades", cada resposta assinalada por um aluno. Analisando estas respostas, é possível fazer um paralelo com a pesquisa de Palheiros (2006, p. 320) com crianças britânicas e portuguesas, na qual a autora também constatou que "algumas crianças referiram razões não musicais como socializar com os colegas e a música ser 'divertida' e 'fácil'".

A opção "Outro motivo" foi assinalada por um aluno, que deu a seguinte resposta: "Quero tocar quase tudo" (Q3, M, 10 anos)" , que demonstra o interesse dele em aprender a tocar vários instrumentos além do violão.

\section{Opinião das crianças sobre o repertório das aulas}

A questão sobre o repertório estudado foi enunciada da seguinte maneira: "O que você acha das músicas que está aprendendo a tocar?". As respostas das crianças para esta questão foram as seguintes:

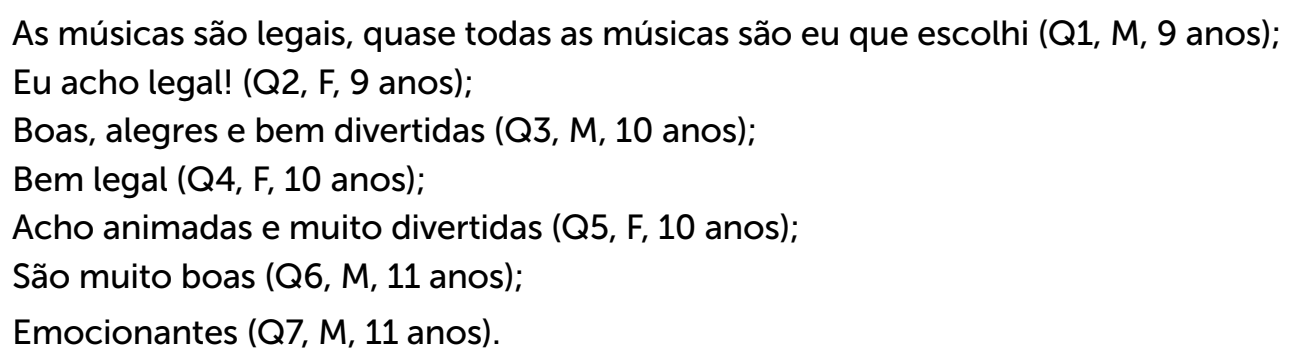

Na sequência, as respostas das crianças foram agrupadas em duas categorias: (1) legais/boas/divertidas; (2) legais porque eu escolhi (ver Quadro 2).

\footnotetext{
$6 \quad$ "With each new acquisition of a skill there is some room for playful exercising of that skill, but boredom soon sets in when one merely exercises the same skill over and over" (DECl; RYAN, 1985, p. 27)

7 Q3, M, 10 anos = Questionário 3, gênero masculino, 10 anos de idade.
} 
Quadro 2. Categorização das respostas da questão 7

\begin{tabular}{ll}
\hline CATEGORIA & R ESPOSTAS \\
\hline & Eu acho legal! (Q2, F, 9 anos) \\
& Bem legal (Q4, F, 10 anos) \\
LEGAIS & São muito boas (Q6, M, 11 anos) \\
BOAS/DIVERTIDAS & Emocionantes (Q7, M, 11 anos) \\
& Boas, alegres e bem divertidas (Q3, M, 10 anos) \\
& Acho animadas e muito divertidas (Q5, F, 10 anos) \\
\hline $\begin{array}{l}\text { LEGAIS PORQUE EU } \\
\text { ESCOLHI }\end{array}$ & $\begin{array}{l}\text { As músicas são legais, quase todas as músicas são eu que escolhi } \\
\text { (Q1, M, 9 anos) }\end{array}$ \\
\hline
\end{tabular}

Fonte: Dados da pesquisa

As respostas das crianças foram agrupadas por semelhança e proximidade semântica, e a maior parte das respostas foi enquadrada na primeira categoria: "legais/boas/ divertidas". De forma geral, a opinião dos alunos sobre o repertório que estavam aprendendo foi muito positiva, nenhum deles respondeu não gostar das músicas.

Tourinho (1995), Cruvinel (2003), Caetano (2012), Santayana (2012) e Rosa (2015) convergem para a importância do repertório de interesse dos alunos como fator motivador para a aprendizagem e, na fala de alguns alunos, surgiu a questão de escolha das músicas.

Um aluno de nove anos respondeu: "As músicas são legais, quase todas as músicas são eu que escolhi". Considerando que todos os alunos que participaram da pesquisa têm aula com o mesmo professor e respostas semelhantes também foram dadas por alunos mais velhos (dados não apresentados neste recorte), é possível perceber que essas falas revelam que de alguma forma o professor possibilitava que os alunos escolhessem parte das músicas do repertório, uma vez que no contexto coletivo muitas vezes não é possível permitir que todas as músicas sejam de interesse pessoal dos alunos, considerando-se a heterogeneidade da turma. De qualqer forma, as possibilidades dadas pelo professor aos estudantes, de ter a chance de opinar pelo próprio repertório, refletia na motivação dos alunos para aprender o instrumento.

\section{Opinião dos alunos sobre as aulas em grupo: a relação com as experiências vicárias}

A opinião dos alunos a respeito das aulas em grupo foi levantada por meio do seguinte enunciado: "O que você acha de ter aulas de violão em grupo?". A seguir, foram transcritas as respostas de cada aluno:

É ruim tocar sozinho e bom tocar com alguém, tem mais som (Q1, $M, 9$ anos);

Eu acho muito legal e divertido (Q2, F, 9 anos); 
Eu acho muito bom, porque você não se sente sozinho e pode compartilhar as músicas com os outros alunos (Q3, $M, 10$ anos);

Legal (Q4, F, 10 anos);

Legal, muito legal ou + ou -, né (Q5, F, 10 anos);

São bem legais, a gente pode compartilhar a música com outra pessoa (Q6, M, 11 anos);

Interessante, dá para ver como o outro toca (Q7, M, 11 anos).

Observando a recorrência de palavras e assuntos nas respostas dos alunos, foi possível agrupá-las em três diferentes categorias, dentre as quais duas estavam diretamente relacionadas à vivência das experiências vicárias: (1) legal; (2) aprender com os outros; (3) compartilhar/tocar com/para os outros (ver Quadro 3):

Quadro 3. Categorização das respostas da questão 6

\begin{tabular}{ll}
\hline CATEGORIA & RESPOSTAS \\
\hline LEGAL & $\begin{array}{l}\text { Eu acho muito legal e divertido (Q2, F, 9 anos) } \\
\text { Legal (Q4, F, 10 anos) } \\
\text { Legal, muito legal ou + ou -, né (Q5, F, 10 anos) }\end{array}$ \\
\hline $\begin{array}{l}\text { APRENDER COM OS } \\
\text { OUTROS }\end{array}$ & Interessante, dá para ver como o outro toca (Q7, M, 11 anos) \\
\hline COMPARTILHAR/TOCAR & $\begin{array}{l}\text { Eu acho muito bom, porque você não se sente sozinho e pode } \\
\text { compartilhar as músicas com os outros alunos (Q3, M, 10 } \\
\text { anos) }\end{array}$ \\
\hline $\begin{array}{l}\text { São bem legais, a gente pode compartilhar a música com } \\
\text { outra pessoa (Q6, M, 11 anos) }\end{array}$ \\
\hline
\end{tabular}

Fonte: Dados da pesquisa

$\mathrm{Na}$ primeira categoria estão agrupadas as respostas principalmente ligadas à palavra "legal" (muito legal, bom, divertido). Em quase todas as respostas agrupadas nas outras categorias também existe alguma referência positiva, como bom, ótima, legal, interessante, importante. Esta opinião positiva se relaciona com um dos motivos mais indicados da questão anterior, na qual os alunos assinalaram que decidiram aprender violão principalmente "porque é divertido". O ambiente lúdico, já citado na revisão deste trabalho, pode ser visto como uma das vantagens propiciadas pelo ensino coletivo.

Dantas (2010, p. 406) constatou que "para os estudantes o fator que mais contribui para a motivação no processo de aprendizagem é a interação no grupo". Santayana (2012) fez uma pesquisa sobre o ensino coletivo de flauta transversal em oficinas culturais no Rio Grande do Sul e observou nas falas dos entrevistados "que as aulas coletivas geraram nos alunos certo estímulo ao perceber que mesmo sendo iniciante no instrumento é possível fazer música e se sentir integrante de um grupo" (SANTAYANA, 2012, p. 27).

A ideia de se sentir integrante de um grupo aparece na resposta de um aluno de dez anos, que comenta: “Eu acho muito bom, porque você não se sente sozinho e pode 
compartilhar as músicas com os outros alunos". De acordo com Dantas (2010, p. 412), "o vínculo estabelecido em torno da música fortalece as relações interpessoais, que, por sua vez, contribui para o desenvolvimento de uma identidade grupal, e a formação de valores e comportamentos".

$\mathrm{Na}$ resposta de outro aluno de nove anos, foi possível perceber a referência à sonoridade do grupo: "É ruim tocar sozinho e bom tocar com alguém, tem mais som". A sonoridade também apareceu em um dos motivos mais assinalados pelos alunos para o aprendizado do instrumento: "Porque gosto do som do violão". Outros autores também encontraram em suas pesquisas a indicação de que a sonoridade obtida no grupo é um fator relevante e estimulante na experiência da prática musical coletiva, como Cruvinel (2003), Dantas (2010) e Caetano (2012).

Um dos alunos, ao expor sua opinião sobre as aulas em grupo, citou a experiência de observar o outro e aprender com ele; por isso, foi incluído na categoria "aprender com os outros", considerada como uma experiência vicária. Azzi (2014) explica que, dentro da Teoria Social Cognitiva, o que Bandura denominou Efeito Modelador ou Aprendizagem por Observação, que está relacionado com a aquisição de comportamentos novos, que o sujeito não apresentava "[...] ou que tinham probabilidade quase nula de ocorrência" (AZZI, 2014, p. 36). A autora continua explanando que "[...] em situações de aprendizagem, o modelo ou o sujeito que está sendo observado exibe comportamentos que o observador não possuía, mas que, após a situação de aprendizagem, passa a ter condição de reproduzir" (Idem).

Outros três alunos citaram palavras como compartilhar, tocar com os outros ou para os outros. Esta categoria foi chamada de "compartilhar/tocar com/para os outros". O ambiente de ensino coletivo proporciona um espaço de compartilhamentos de vivência de diferentes experiências vicárias, onde, além de poderem tocar juntos, é muito comum um aluno tocar para o outro ver, mostrando algo que aprendeu e motivando o outro a tocar também. Isso fica bem claro na resposta de um aluno de onze anos: "São bem legais, a gente pode compartilhar a música com outra pessoa".

No contexto do ensino coletivo, além do modelo do professor, os alunos encontram também os modelos de seus pares, e suas respostas demonstram que eles têm consciência da presença dos modelos e que podem aprender com eles. Por isso, além da questão aberta, o levantamento sobre a vivência de experiências vicárias (e de outras fontes de eficácia) foi realizado por meio de uma questão em escala Likert de cinco pontos. $O$ enunciado da questão era assim redigido: "Agora eu gostaria que você me dissesse o quanto se sente capaz de:" e na sequência foram apresentadas seis alternativas que partiam do número 1 (pouco capaz) até o número 5 (muito capaz). Para facilitar a análise das respostas das crianças, foram agrupadas em três níveis, assim divididos: respostas nos níveis 1 e 2 da escala foram consideradas no nível "pouco capaz"; respostas nos níveis 4 e 5 foram consideradas "capaz/muito capaz"; e respostas no nível 3 da escala ficaram num nível "neutro".

Foi questionado às crianças a respeito da capacidade delas de aprender com a observação de colegas. Nesta questão, quatro alunos assinalaram que se sentiam pouco capazes de aprender a tocar uma música observando um colega que já sabe tocá-la; 
dois responderam de forma neutra e um afirmou se sentir muito capaz de aprender observando o colega. Quando questionados sobre a possibilidade de aprender por meio da observação do professor, isto é, eles observando o professor demonstrar como tocá- la, cinco crianças responderam que se consideravam pouco capazes e duas afirmaram se sentir muito capazes de aprender (ver Figs. 1 e 2).

Figura 1. Aprender a tocar uma música observando um colega que já sabe tocá-la

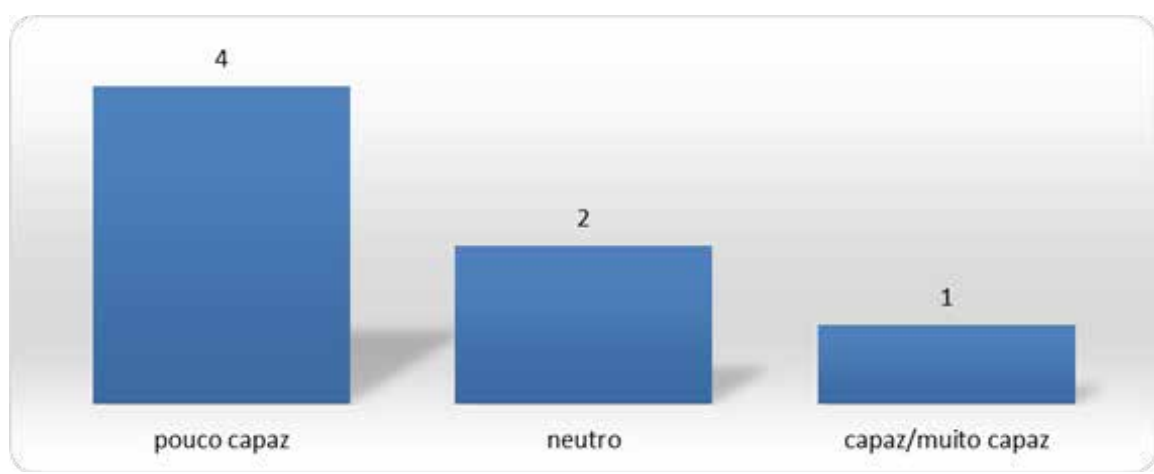

Fonte: Dados da pesquisa

Figura 2. Tocar de forma semelhante ao professor

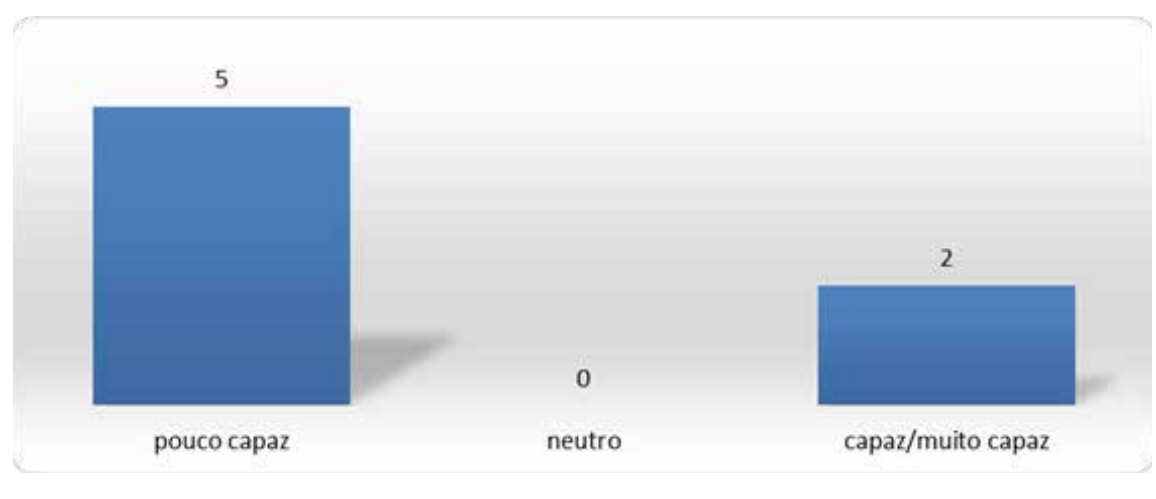

Fonte: Dados da pesquisa

Estes dados demonstraram que alguns processos de aprendizagem específicos, vivenciados no contexto das aulas de violão em grupo, ainda não traziam um processo de modelação de aprendizagem efetivo (processo vicariante), nem ao observar os pares e nem ao observar o professor que, para as crianças, encontra-se num nível de desempenho muito superior ao delas. De acordo com Azzi e outros (2014), quanto mais similares forem as características pessoais do modelo e do observador, maior a relevância da informação sobre as crenças de autoeficácia do indivíduo. “Dentre essas características, estão o gênero, a idade, os níveis socioeconômico e educacional e a etnia, sendo que idade e gênero parecem ter maior influência" (AZZI et al., 2014, p. 29). 


\section{Experiências diretas de êxito}

Utilizando também a escala Likert de cinco pontos, foi questionado o quanto as crianças se sentiam capazes de aprender a tocar uma música nova no violão. O resultado foi o seguinte: uma criança assinalou a parte negativa da escala, afirmando sentir-se pouco capaz de aprender a tocar uma música nova no violão; quatro crianças responderam de forma neutra e duas crianças afirmaram sentir-se capazes ou muito capazes de aprender a tocar uma música nova no violão (ver Fig. 3).

Figura 3. Aprender a tocar uma música nova no violão

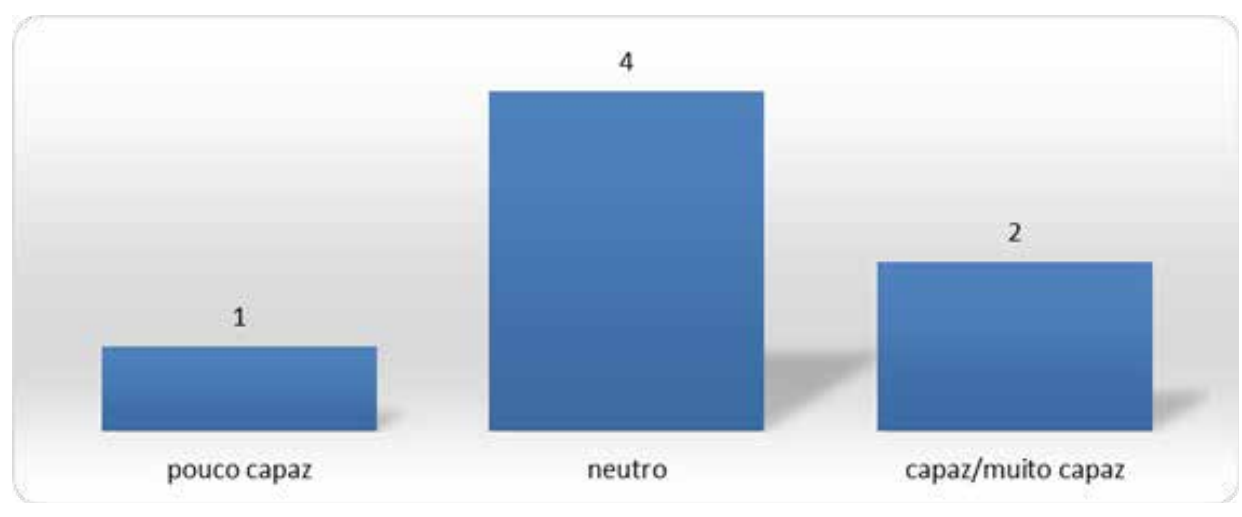

Fonte: Dados da pesquisa

Tocar uma música no violão é uma experiência direta e, quando essa experiência é positiva, é chamada de experiência de êxito, de acordo com Bandura (1994). Conforme o aluno vai vivenciando experiências de sucesso na execução de novas peças, essa expectativa de ter novamente sucesso representa uma crença de autoeficácia elevada. A experiência direta é a fonte que produz maior influência na construção de um senso de autoeficácia fortalecido (BANDURA, 1994). É importante observar que as crianças eram iniciantes no estudo do violão, portanto, sem muitas experiências com este instrumento. Desta forma, é compreensível que tenham respondido de forma neutra ou se julgado pouco capazes de aprender.

A outra questão relativa à experiência direta indagava sobre a capacidade de tocar uma música junto com os colegas (em grupo) e, de forma geral, as respostas ficaram bem distribuídas: três alunos afirmaram se sentir "pouco capaz" de tocar uma música junto com seus colegas, um respondeu de forma neutra e outros três alunos assinalaram que se sentiam capazes ou muito capazes de tocar uma música junto com seus colegas (ver Fig. 4). 


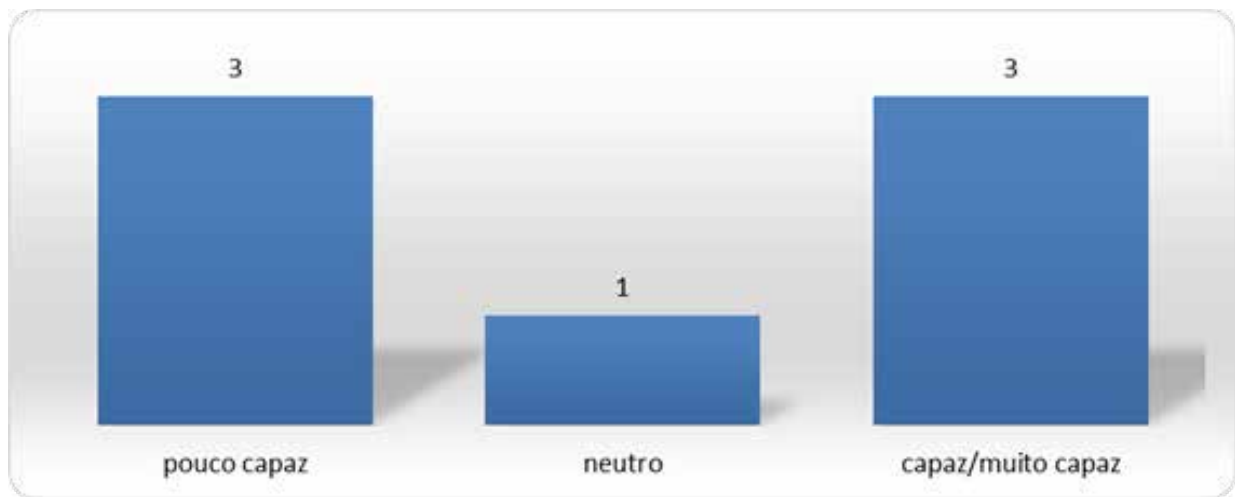

Fonte: Dados da pesquisa

Tocar junto com os colegas, que já foi citado pelos próprios alunos como um ponto positivo proporcionado pelas aulas coletivas, também pode ser um desafio. $O$ resultado permite observar que, do total de sete crianças, somente três sentiam-se capazes ou muito capazes de tocar uma música junto com seus colegas. É provável que estes alunos já tenham tido experiências diretas de êxito ao tocar com seus colegas e, por isso, apresentaram um senso de eficácia forte para esta atividade. Bandura (1994) afirma que a maneira mais eficaz de criar um senso de autoeficácia fortalecido é por meio das experiências diretas de êxito.

\begin{abstract}
Quando se pretende alterar as crenças de autoeficácia a partir dessa fonte de informação, vários aspectos importantes precisam ser considerados nesse processo de mudança, tais como: a) as experiências anteriores; b) a quantidade de esforço necessário; c) a dificuldade da tarefa; d) a quantidade de apoio externo que se recebe; e) as demandas situacionais sob as quais a tarefa se realizará. (BANDURA, 1997 apud AZZI et al., 2014, p. 26).
\end{abstract}

Dessa forma, conforme aponta Azzi e outros (2014), um professor que pretenda atuar em prol do fortalecimento da crença de eficácia dos alunos por meio das experiências diretas, visando proporcionar experiências de êxito, por exemplo, poderá planejar atividades com diferentes níveis de dificuldade que atendam às diferenças individuais entre os alunos; fornecer orientação necessária antes, durante e após a realização das atividades; incentivar a manutenção do foco; e estabelecer objetivos de curto, médio e longo prazos.

\title{
Indicadores fisiológicos
}

Os indicadores fisiológicos neste estudo foram associados às experiências vivenciadas pelas crianças ao se apresentarem, considerando-se aspectos da ansiedade que frequentemente acompanham este processo. A ansiedade na performance tem sido pesquisada especialmente no contexto da preparação de execução da performance instrumental, como indicado em Ray (2009). Neste estudo, não foi tratada a ansiedade com um olhar na especificidade infantil, mas como um fator comum para o músico de 
diferentes idades. Foi considerada a ansiedade no contexto da performance pública. Assim, foi questionado, usando a questão com escala Likert, o quanto o aluno se sentia capaz de se apresentar sozinho diante de uma plateia. A parte negativa da escala foi assinalada por quatro crianças, enquanto uma assinalou a parte neutra, uma a parte positiva e uma criança não respondeu (ver Fig. 5). Porém, ao serem questionadas quanto à capacidade de se apresentarem junto com seus colegas diante de uma plateia, duas crianças assinalaram que se sentiam pouco capazes; duas assinalaram a resposta neutra; e três crianças responderam sentir-se muito capazes (ver Fig. 6).

Figura 5. Apresentar-se sozinho diante de uma plateia

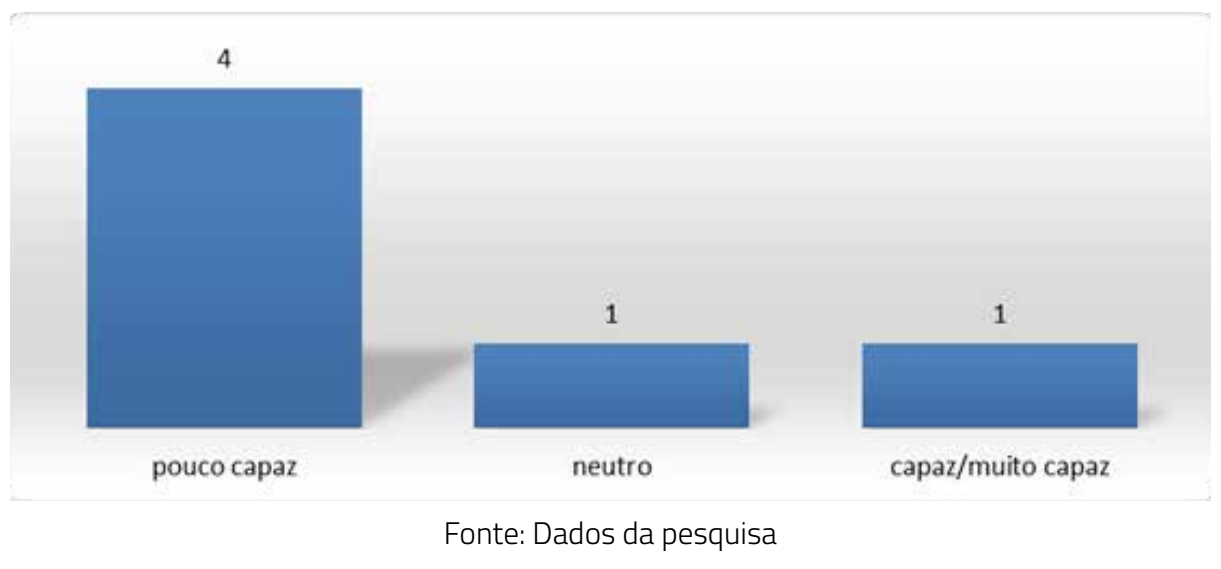

Figura 6. Apresentar-se junto com seus colegas diante de uma plateia

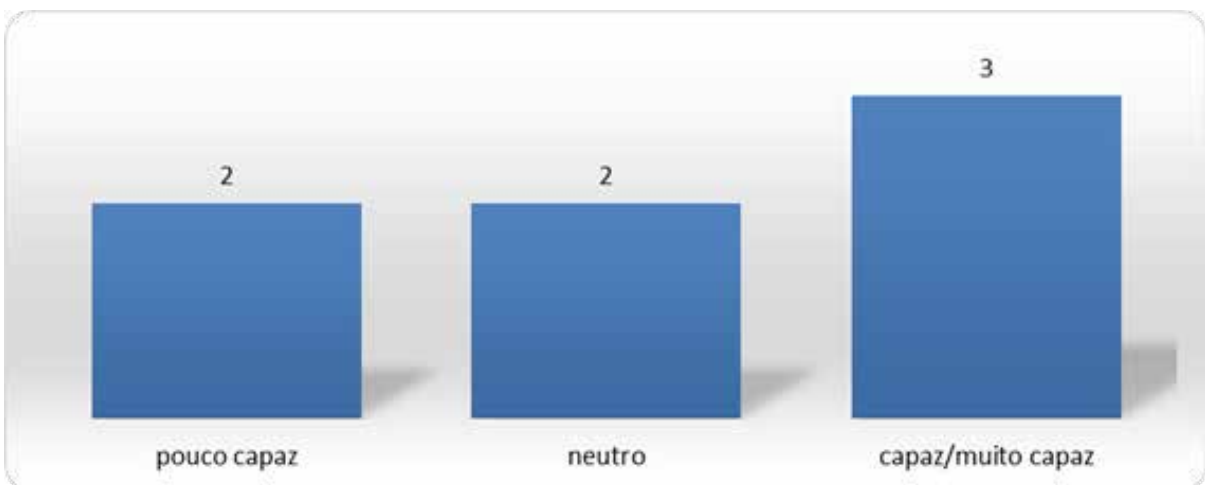

Fonte: Dados da pesquisa

Observou-se, portanto, que a maior parte das crianças não se sentia capaz de se apresentar sozinha diante de uma plateia. Na pesquisa de Rosa (2015, p. 67), a maior parte dos alunos afirmou nunca sentir alegria/satisfação tocando em apresentações. De acordo com o autor, "[...] a sugestão mais recorrente na literatura relaciona a percepção negativa da performance com o fator ansiedade". Stencel, Soares e Moraes (2012) explicam que, entre outros componentes, a ansiedade pode ser percebida por meio de indicadores fisiológicos como distúrbios nos padrões respiratórios, suor, boca seca, coração acelerado, aumento de adrenalina e cortisona, distúrbios gastrointestinais. Segundo estes autores, “[...] parece que a exposição pública na prática musical traz mais 
desconforto do que uma atitude prazerosa, porém tirar proveito desse aspecto favorável pode ser usado como um elemento contributivo ao nível técnico da performance" (STENCEL; SOARES; MORAES, 2012, p. 39).

Azzi e outros (2014) explicam que, dependendo da construção das experiências do indivíduo (experiências de sucesso ou de fracasso em apresentações anteriores) e da intensidade do nível de ativação do indivíduo, isto é, de seu estado de alerta físico para ação, a informação advinda dos indicadores fisiológicos pode ter impacto diferente na constituição da crença de autoeficácia do aluno.

É importante apontar que [...] esse nível de ativação pode ser percebido por diferentes comportamentos como sudorese excessiva, mãos trêmulas, rubor facial, e o indivíduo pode interpretá-los positivamente (como uma forma de ativação e preparação para a atividade) ou negativamente (como algo que irá prejudicar o desempenho da atividade). (AZZI et al.,2014, p. 32).

Já o resultado sobre o aumento das crenças de autoeficácia das crianças, observado quando questionadas sobre a possibilidade da apresentação pública em contexto coletivo, veio ao encontro do estudo de Stencel, Soares e Moraes (2012), que trouxe resultados semelhantes, enumerando algumas razões citadas pelos alunos que preferem tocar em grupo:

Tanto homens, como mulheres, preferem tocar em grupo, pois é mais cômodo, há interação; porque dá uma sensação maior de segurança; dá mais empolgação; porque há união de ideias, produção e maior trabalho; porque não estou sozinho em cima do palco; porque divide as responsabilidades; dá mais tranquilidade; meus erros são escondidos; porque a atenção do público não está totalmente em mim. (STENCEL; SOARES e MORAES, 2012, p. 41).

Outra pesquisa que obteve resultados semelhantes foi a de Cruvinel (2003), que comenta sobre a motivação dos alunos de ensino coletivo para se apresentarem em grupo, comparando as aulas individuais.

Outro ponto interessante, que merece ser destacado, se refere ao fato de que o ensino coletivo propicia uma grande motivação causada pelas apresentações públicas; ao contrário da aula individual, onde o solista, por estudar e tocar sozinho, sente medo ou insegurança no palco. Os alunos que estudam através do ensino coletivo se sentem confiantes e querem mostrar (para todas as pessoas possíveis!) o trabalho desenvolvido em conjunto, em várias apresentações e locais diferentes. (CRUVINEL, 2003, p. 181).

\section{Persuasão verbal}

As últimas questões se referiam à persuasão verbal vinda dos colegas e do professor. A primeira pergunta questionava o seguinte: "Se um colega elogiar o jeito que você está tocando, como você reage?". A seguir foram transcritas as respostas dos alunos:

Eu falo obrigado (Q1, M, 9 anos);

Envergonhada! (Q2, F, 9 anos); 
Eu agradeço e pergunto se ele quer aprender a tocar a música (Q3, M, 10 anos);

Eu digo obrigado (Q4, F, 10 anos);

Muito feliz ou muito tímida (Q5, F, 10 anos);

Muito bem, eu agradeço a ele por ter me elogiado (Q6, $M, 11$ anos);

Muito obrigado, você também é bom (Q7, $M, 11$ anos).

As respostas dos alunos foram agrupadas, considerando que um mesmo participante poderia dar respostas diversas que se aplicavam em diferentes categorias. As respostas foram asssim organizadas: (1) gratidão; (2) bem-estar; (3) timidez (ver Quadro 4):

\begin{tabular}{|c|c|}
\hline CATEGORIA & RESPOSTAS \\
\hline \multirow{4}{*}{ GRATIDÃO } & Eu falo obrigado (Q1, M, 9 anos) \\
\hline & $\begin{array}{l}\text { Eu agradeço e pergunto se ele quer aprender a tocar a música (Q3, } \\
\mathrm{M}, 10 \text { anos) }\end{array}$ \\
\hline & Eu digo obrigado (Q4, F, 10 anos) \\
\hline & Muito obrigado, você também é bom (Q7, M, 11 anos) \\
\hline BEM-ESTAR & Muito bem, eu agradeço a ele por ter me elogiado (Q6, M, 11 anos) \\
\hline \multirow{2}{*}{ TIMIDEZ } & Muito feliz ou muito tímida (Q5, F, 10 anos) \\
\hline & Envergonhada! (Q2, F, 9 anos) \\
\hline
\end{tabular}

Na hipótese de receber um elogio de um colega, a maior parte dos alunos respondeu de forma educada que agradeceria o elogio. Um aluno de dez anos complementou: "Eu agradeço e pergunto se ele quer aprender a tocar a música"; e outro, de onze anos, devolveria o elogio da seguinte forma: "Muito obrigado, você também é bom".

De acordo com Bandura (1986; 1997 apud AZZI et al., 2014, p. 30), o impacto da persuasão na construção das crenças de autoeficácia "depende da credibilidade, do conhecimento e da experiência da fonte persuasiva na atividade em questão". Assim, é provável que o impacto do elogio de um colega não seja tão grande quanto o impacto do elogio do professor, que certamente possui mais experiência na atividade de tocar violão do que os colegas.

A questão sobre a persuasão verbal do professor estava assim redigida: "Se o professor elogiar o jeito que você está tocando, como você se sente?". Abaixo estão transcritas as respostas dos alunos:

Feliz por aprender a melhor tocar uma música (Q1, M, 9 anos);

Envergonhada e elogiada (Q2, F, 9 anos);

Eu fico muito muito feliz e agradeço (Q3, $M, 10$ anos);

Bem (Q4, F, 10 anos);

Envergonhada (Q5, F, 10 anos); 
Melhor ainda (Q6, M, 11 anos);

Consegui, legal (Q7, $M, 11$ anos).

Analisando as respostas dos alunos, duas categorias foram criadas para agrupá-las, considerando a recorrência das palavras e a proximidade semântica: (1) bem-estar; (2) timidez (ver Quadro 5):

\begin{tabular}{ll} 
CATEGORIA & RESPOSTAS \\
\hline & Eu fico muito muito feliz e agradeço (Q3, M, 10 anos) \\
& Feliz por aprender a melhor tocar uma música (Q1, M, 9 anos) \\
BEM-ESTAR & Bem (Q4, F, 10 anos) \\
& Melhor ainda (Q6, M, 11 anos) \\
& Consegui legal (Q7, M, 11 anos) \\
\hline \multirow{2}{*}{ TIMIDEZ } & Envergonhada e elogiada (Q2, F, 9 anos) \\
& Envergonhada (Q5, F, 10 anos) \\
\hline
\end{tabular}

Diferentemente da questão anterior, apenas um aluno respondeu que agradeceria o elogio do professor: "Eu fico muito, muito feliz e agradeço". Por este motivo, a categoria gratidão (que agrupou o maior número de respostas na questão anterior) foi extinta nesta categorização, e a resposta foi agrupada à categoria bem-estar.

Mais da metade dos alunos afirmou sentir-se bem, feliz ou alegre ao receber um elogio do professor, mas é interessante destacar algumas respostas desta categoria que, além dos sentimentos positivos, denotam um senso de eficácia. Considerando a possibilidade de o professor elogiar a forma como está tocando, um aluno de nove anos escreveu que se sentiria: "(fico) feliz por aprender a melhor tocar uma música"; e um aluno de onze anos disse que comemoraria: "Consegui, legal". De acordo com Azzi e outros (2014), elogios e feedbacks podem funcionar como uma forma de persuasão verbal na medida em que tendem a levar o indivíduo a acreditar que está conseguindo realizar a tarefa, fortalecendo seu senso de autoeficácia.

É importante levar em consideração a explicação de Bandura (apud AZZI et al., 2014), na qual o autor afirma que, quanto maior a credibilidade, o conhecimento e a experiência da fonte persuasiva, maior o impacto da persuasão no senso de eficácia do indivíduo. Assim, ao receber um elogio do professor que realmente conhece muito de música, o aluno se sente ainda mais feliz do que ao receber um elogio de um colega.

$\mathrm{Na}$ categoria timidez, duas alunas responderam que se sentiriam envergonhadas. Kodama (2008) comenta sobre a velha expressão popular "é só elogiar..." e explica por que muitas vezes não conseguimos repetir o feito depois de um elogio.

Existem duas possibilidades: a primeira seria que, ao ser elogiada, a pessoa se emociona e o seu pensamento se volta à sua alegria e não mais para a atividade na qual estava concentrada. Por outro lado, com o elogio, o indivíduo pode sen- 
tir uma obrigação de repetir o feito, e essa pressão pode resultar em ansiedade $e$ preocupação. (KODAMA, 2008, p. 35).

A explicação de Kodama (2008) pode ajudar a entender por que as alunas se sentiram envergonhadas ao receber um elogio do professor, pois aponta para um cuidado na forma de elogiar, para que não se torne constrangedor. Ao mesmo tempo, esta fonte de autoeficácia pode ser uma ferramenta muito importante e, ao estruturar atividades que objetivem o sucesso dos alunos, "os professores podem utilizar-se da persuasão social para incentivá-los a buscar o êxito por meio de tarefas adequadas, orientações efetivas, palavras de apoio e de avaliações que fortaleçam a crença de eficácia dos alunos" (AZZI et al., 2014, p. 31). Neste sentido, entende-se que a persuasão verbal, no contexto deste estudo, era muito mais eficaz no fortalecimento das crenças de autoeficácia dos estudantes, quando eles recebiam elogios do professor indicando que este reconhecia o bom desempenho.

\section{Considerações finais}

O presente estudo trouxe em relevo dados sobre a motivação e as crenças de autoeficácia de sete crianças para aprender violão no contexto do ensino coletivo. Os resultados obtidos indicaram que as crianças possuíam principalmente motivação intrínseca para aprender o instrumento, sendo pouco influenciadas, para esta prática, por motivos externos. Neste sentido, o repertório executado era muito apreciado e aceito pelas crianças, o que reforça a motivação geral para o estudo do instrumento, para a motivação para estudar.

Em relação às crenças de autoeficácia, foi observado que as experiências vicárias estavam presentes no contexto do ensino coletivo e que os estudantes valorizavam a possibilidade de "aprender com os outros", "trocar", "compartilhar", além de acharem "legal" a aprendizagem junto ao grupo. Ainda nesta categoria, foi possivel ver que alguns processos de modelação (fruto de experiências vicárias), para aprendizagem de novo repertório, não estavam colaborando para aumentar as crenças de autoeficácia dos alunos quando o modelo partia de algum colega mais adiantado ou do professor. Os dados demonstraram que as crianças que eram iniciantes e que observavam modelos de desempenho num nível muito superior ao delas não encontravam, no processo vicário, um modelo para aumentar suas crenças de autoeficácia. Estes dados indicam, portanto, que o professor, ao utilizar o processo de modelação, deve estar atento à forma como o modelo é apresentado, para estimular de forma atraente o desejo pelo bom desempenho nas crianças. Em relação às experiências de êxito das crianças, observou-se que ainda não eram muito percebidas por elas, pois eram iniciantes no estudo do violão. A questão que teve maior índice "capaz/muito capaz" na avaliação do êxito foi associada à realização de performances coletivas, ao tocar em conjunto com os colegas. Sobre os indicadores fisiológicos, observou-se que a experiência de tocar em público individualmente foi indicada como competência ainda a ser dominada, e que a ansiedade e a insegurança, que também são fonte de aumento ou diminuição do senso 
de eficácia, ainda precisavam ser mais controladas. Já a persuasão verbal, exercida pelo professor, foi analisada como uma importante fonte para o aumento das crenças de eficácia das crianças, principalmente quando combinada a outras fontes, como experiências diretas, por exemplo.

A partir dos dados, foi possível vislumbrar algumas orientações para que o professor que atua com ensino coletivo de instrumento colabore, de forma atenta, para a manutenção da motivação dos alunos e para o aumento de suas crenças de autoeficácia. Neste sentido, sugere-se que o professor: (1) observe se o repertório é adequando e interessante para todos; (2) promova situações de aprendizagem que proporcionem experiências de êxito para as crianças (no contexto do grupo e individualmente); (3) utilize de forma responsável o "poder" da persuasão verbal para fortalecer nos jovens estudantes sua autoconfiança; (4) utilize os pares e a si mesmo como modelo para promover a aprendizagem por meio das experiências vicárias; e, finalmente, (5) proporcione diferentes atividades de performance pública com as crianças (individuais e em grupo), para que aos poucos elas possam sentir-se mais confiantes, aprendendo a lidar com seus estados fisiológicos, para que possam se apresentar com mais motivação e tranquilidade.

Assim, este estudo traz contribuições novas aos estudos anteriormente citados de Tourinho (2006), Vieira (2009), Cruvinel (2003), Dantas (2010) e Brazil e Tourinho (2013), pois inclui um novo olhar para o objeto em questão, sob a ótica das crenças de autoeficácia. Além disso, os resultados do estudo corroboram com os estudos anteriores ao indicar que o contexto de ensino coletivo de violão possibilita a aprendizagem por meio dos pares (aprender em conjunto), facilita o engajamento e o sentimento de pertencimento, favorece a melhora da sonoridade, além de demosntrar o potencial que tal contexto traz para motivação geral do aluno e para o fortalecimento de suas crenças de autoeficácia.

\section{Referências}

ARAÚJO, R. C. Motivação para prática e aprendizagem da música. In: ARAÚJO, R. C., RAMOS, D. (Orgs.). Estudos sobre motivação e emoção em cognição musical. Curitiba: Ed. UFPR, 2015.

AZZI, R. G. et al. Crenças de eficácia pessoal e coletiva. In: AZZI, R. G.; VIEIRA, D. A. (Orgs.). Crenças de eficácia em contexto educativo. São Paulo: Casa do Psicólogo, 2014.

AZZI, R. G.; POLYDORO, S. A. J. Auto-eficácia proposta por Albert Bandura. In: AZZI, R. G.; POLYDORO, S. A. J. (Orgs.). Auto-eficácia em diferentes contextos. São Paulo: Editora Alínea, 2006. p. 9-23.

BANDURA, A. Self-efficacy: Toward a unifying theory of behavioral change. Psychological Review, v. 84, n. 2, p. 191-215, mar. 1977. Disponível em: <http://teachlearn.caltech. edu/documents/82-bandura_self-efficacy.pdf>. Acesso em: 7 abr. 2015. 
BANDURA, A. Self-efficacy. In: RAMACHAUDRAN, V. S. (Ed.). Encyclopedia of human behavior. V. 4. New York: Academic Press, 1994. p. 71-81.

BANDURA, A. Exercise of personal and collective efficacy in changing societies. In: BANDURA, A. Self-efficacy in changing societies. Cambridge: Cambridge University Press, 1995.

BATTISTI, D. Um estudo sobre as crenças de autoeficácia no ensino coletivo de violão. 2016. 98 f. Dissertação (Mestrado em Música) - Setor de Artes, Comunicação e Design, Universidade Federal do Paraná, Curitiba, 2016. Disponível em: <http://hdl.handle. net/1884/44070>. Acesso em: 25 ago. 2017.

BATTISTI, D.; ARAÚJO, R. C. Elaboração e validação de um questionário sobre as crenças de autoeficácia de alunos de violão em um contexto de ensino coletivo. In: ANAIS do XXII Congresso da ABEM - Associação Brasileira de Educação Musical. Natal: ABEM, 2015, p. 1-10.

BRAGA, P. D. A. Oficina de violão: estrutura de ensino e padrões de interação em um curso coletivo a distância. Tese (Doutorado em Música) - Programa de Pós-graduação em Música, Universidade Federal da Bahia, Salvador, 2009.

BRAZIL, M. O material didático em aulas coletivas de violão como fonte de motivação e de crença de autoeficácia. In: SEMINÁRIO NACIONAL DE PESQUISA EM MÚSICA DA UFG, 12., 2013a, Goiânia. Anais... Goiânia: UFG, 2013a, p. 140-142. Disponível em: <https://mestrado.emac.ufg.br/up/270/o/13\%C2\%BA_SEMPEM.pdf>. Acesso em: 18 maio 2015.

BRAZIL, M. Ensino de violão para iniciantes: uma reflexão sobre o uso das tonalidades. In: SIMPÓSIO ACADÊMICO DE VIOLÃO DA EMBAP, 7., 2013, Curitiba. Anais... Curitiba: EMBAP, 2013b, p. 162-171. Disponível em: <http://www.embap.pr.gov.br/arquivos/File/ simposio/violao2014/Anais_do_VII_Simposio_EMBAP.pdf>. Acesso em: 05 maio 2015.

BRAZIL, M. TOURINHO, C. Composição coletiva como alternativa para a geração de repertório em aulas de violão em grupo. In: CONGRESSO NACIONAL DA ASSOCIAÇÃO BRASILEIRA DE EDUCAÇÃO MUSICAL, 21., 2013, Pirenópolis. Anais... João Pessoa: Editora da UFPB, 2013a. Disponível em: <http://www.abemeducacaomusical.com.br/sistemas/anais/congressos/ABEM_2013_p.pdf>. Acesso em: 05 maio 2015.

CAETANO, M. T. O. A. Ensino coletivo de flauta doce na educação básica: práticas pedagógicas musicais no Colégio Pedro II. 2012. 174 f. Dissertação (Mestrado em Música) - Programa de Pós-graduação em Música, Universidade Federal do Rio de Janeiro, Rio de Janeiro, 2012. Disponível em: <http://objdig.ufrj.br/26/dissert/780390.pdf>. Acesso em: 13 jan. 2016. 
CONDESSA, J. A motivação dos alunos para continuar seus estudos em música. 2011. 109 f. Tese (Doutorado em Música) - Programa de Pós-graduação em Música, Universidade Federal do Rio Grande do Sul, Porto Alegre, 2011. Disponível em: <http://hdl. handle.net/10183/32473>. Acesso em: 18 out. 2013.

COSTA, E. R.; BORUCHOVITCH, E. Auto-eficácia e a motivação para aprender: considerações para o desempenho escolar dos alunos. In: AZZI, R. G.; POLYDORO, S. A. J. (Orgs). Auto-eficácia em diferentes contextos. Campinas: Editora Alínea, 2006. p. 87-109.

CERESER, C. M. I. As crenças de autoeficácia dos professores de música. 2011. 182 f. Tese (Doutorado em Música) - Programa de Pós-graduação em Música, Universidade Federal do Rio Grande do Sul, Porto Alegre, 2011. Disponível em: <https://www.lume. ufrgs.br/bitstream/handle/10183/31429/000781480.pdf?sequence=1>. Acesso em: 08 out. 2014.

CRUVINEL, F. M. Efeitos do ensino coletivo na iniciação instrumental de cordas: a educação musical como meio de transformação social. 2003. 321 f. Dissertação (Mestrado em Música) - Escola de Música e Artes Cênicas, Universidade Federal de Goiás, Goiânia, 2003. Disponível em: <https://mestrado.emac.ufg.br/p/2795-2001>. Acesso em: 23 mar. 2015.

DANTAS, T. Aprendizagem do instrumento musical realizada em grupo: fatores motivacionais e interações sociais. In: SIMPÓSIO BRASILEIRO DE PÓS-GRADUANDOS EM MÚSICA, 1., 2010, Rio de Janeiro. Anais... Rio de Janeiro: UNIRIO, 2010. Disponível em: <http://www4.unirio.br/simpom/textos/SIMPOM-Anais-2010-TaisDantas.pdf>. Acesso em: 17 fev. 2015.

DECl, E. L.; RYAN, R. M. Intrinsic motivation and self-determination in human behavior. New York: Plenum, 1985.

GALAND, Benoît; BOURGEOIS, Étienne. Motivar-se para aprender. Campinas: Autores Associados, 2011.

KODAMA, M. K. Tocando com concentração e emoção. São Paulo: Editora Som, 2008.

McPHERSON, G. E.; O'NEILL, S. A. Motivation. In: PARNCUTT, R.; McPHERSON, G. (Eds.). The science and psychology of music performance: Creative strategies for teaching and learning. New York: Oxford University Press, 2002. p. 31-46.

ORTINS, F.; CRUVINEL, F. M.; LEÃO, E. O papel do professor no ensino coletivo de cordas: facilitador do processo ensino aprendizagem e das relações interpessoais. In: ENCONTRO NACIONAL DE ENSINO COLETIVO DE INSTRUMENTO MUSICAL, 1., 2004, Goiânia. 
Anais... Goiânia: 2004, p. 60-67.

PAJARES, F.; OLAZ, F. Teoria social cognitiva e auto-eficácia: uma visão geral. In: BANDURA, A.; AZZI, R. G.; POLYDORO, S. Teoria Social Cognitiva: conceitos básicos. Porto Alegre: Artmed, 2008. p. 97-114.

PALHEIROS, G. B. Funções e modos de ouvir música de crianças e adolescentes, em diferentes contextos. In: ILARI, B. S. Em busca da mente musical: ensaios sobre os processos cognitivos em música - da percepção à produção. Curitiba: Ed. da UFPR, 2006.

RAY, S. Considerações sobre o pânico do palco na preparação de uma performance musical. In: ILARI, B. E ARAUJO, R. C. (Orgs.). Mentes em Música. Curitiba: Deartes, 2009. p. $158-178$.

RIBEIRO, G. M. Autodeterminação para aprender nas aulas de violão a distância online: uma perspectiva contemporânea da motivação. 2013. 241 f. Tese (Doutorado em Música) - Instituto de Artes, Universidade Federal do Rio Grande do Sul, Porto Alegre, 2013. Disponível em: <http://www.lume.ufrgs.br/bitstream/handle/10183/76731/000894548. pdf? sequence=1>. Acesso em: 20 jun. 2014.

ROSA, A. R. Z. A motivação do adolescente para a aprendizagem e a prática do violão na cidade de Curitiba (PR). 2015. 103 f. Dissertação (Mestrado em Música) - Programa de Pós-graduação em Música, Universidade Federal do Paraná, Curitiba, 2015. Disponível em: <http://dspace.c3sl.ufpr.br:8080/dspace/handle/1884/38827>. Acesso em: 09 jan. 2016.

SANTAYANA, R. Ensino coletivo de flauta transversal: Um estudo de caso nas oficinas culturais SESI-música. 2012. 41 f. Monografia (Especialização em Pedagogia da Arte) Faculdade de Educação, Universidade Federal do Rio Grande do Sul, Porto Alegre, 2012. Disponivel em: <http://hdl.handle.net/10183/71621>. Acesso em: 14 jan. 2016.

STENCEL, E. B.; SOARES, L. F.; MORAES, M. J. C. Ansiedade na performance musical: aspectos emocionais e técnicos. In: 8 Simpósio de Comunicações e Artes Musicais. Anais... Florianópolis: Universidade do Estado de Santa Catarina, 2012. p. 37-46.

TEIXEIRA, M. S. B. Ensino Coletivo de Violão: Diferentes Escritas no Aprendizado de Iniciantes. 2008. 40 f. Monografia (Licenciatura em Música) - Instituto Villa-Lobos do Centro de Letras e Artes, UNIRIO, Rio de Janeiro, 2008. Disponível em: <http://www. domain.adm.br/dem/licenciatura/monografia/mauricioteixeira.pdf $>$. Acesso em: 26 jun. 2014.

TOURINHO, A. C. A motivação e o desempenho escolar na aula de violão em grupo. Dissertação (Mestrado em Música) - Programa de Pós-Graduação em Música, Universi- 
dade Federal da Bahia, Salvador, 1995.

TOURINHO, A. C. A motivação e o desempenho escolar na aula de violão em grupo: Influência do repertório de interesse do aluno. Ictus - Periódico do PPGMUS/UFBA, Bahia, v. 4, 2002. Disponível em: <http://www.ictus.ufba.br/index.php/ictus/article/viewFile/45/52>. Acesso em: 16 out. 2013.

TOURINHO, A. C. Ensino coletivo de violão: proposta para disposição física dos estudantes em classe e atividades correlatas. In: SEMINÁRIO NACIONAL DE ARTE E EDUCAÇÃO, 20., 2006, Montenegro. Anais... Montenegro: Ed. da Fundarte, 2006. Disponível em: <http://artenaescola.org.br/sala-de-leitura/artigos/artigo.php?id=69356\&>. Acesso em: 04 maio 2015.

TOURINHO, C. Ensino coletivo de violão: princípios de estrutura e organização. REVISTA ESPAÇO INTERMEDIÁRIO, São Paulo, v. I, n. II, p. 83-93, nov. 2010. Disponível em: <https://pt.scribd.com/doc/170024144/Ensino-Coletivo-de-Violao-Principios-de-Estrutura-e-Organizacao-CRISTINA-TOURINHO-1>. Acesso em: 12 jan. 2016.

TOURINHO, C.; AZZI, R. G. Ensino de Violão para alunos não violonistas na Graduação em Música da Escola de Música da UFBA: estratégias para desenvolver o aprendizado. In: SIMPÓSIO DE COGNIÇÃO E ARTES MUSICAIS, 10., 2014, Campinas. Anais... Campinas: UNICAMP, 2014. p. 199-206. Disponível em: <http://www.abcogmus.org/documents/SIMCAM10.pdf>. Acesso em: 12 jan. 2016.

VIEIRA, A. Professores de violão e seu modo de ser e agir na profissão: um estudo sobre as culturas profissionais no campo da música. 2009. 179 f. Dissertação (Mestrado em Música) - Programa de Pós-graduação em Música, Universidade Federal do Rio Grando do Sul, Porto Alegre, 2009. Disponível em: <http://www.lume.ufrgs.br/handle/10183/17370>. Acesso em: 31 mai. 2014.

VIEIRA, G.; RAY, S. Ensino coletivo de violão: Técnicas de arranjo para o desenvolvimento pedagógico. In: CONGRESSO REGIONAL DA ISME NA AMÉRICA LATINA; ENCONTRO ANUAL DA ABEM, 16., 2007, Campo Grande. Anais... Campo Grande, 2007. Disponível em: <http://www.abemeducacaomusical.org.br/Masters/anais2007/Data/html/pdf/ art_e/Ensino\%20coletivo\%20de\%20violao\%20tecnicas\%20de\%20arranjo\%20Gabriel. pdf>. Acesso em: 26 jun. 2014. 